\title{
Chemical Contamination and Toxicity of Sediments from the Gunsan Coast, Korea
}

\author{
Wan-Seok Lee, Minkyu Choi*, Dong-Woon Hwang, In-Seok Lee and Sook Yang Kim \\ Marine Environment Research Division, National Fisheries Research and Development Institute (NFRDI), Busan 619-705, Korea
}

\begin{abstract}
Polycyclic aromatic hydrocarbons (PAHs), butyltins (BTs), nonylphenol (NP), and fecal sterols concentrations in sediments were investigated from Gunsan coast of Korea to evaluate organic pollution from anthropogenic activities. Sediment toxicity was also examined by bacterial bioluminescence toxicity test (Vibrio fischeri). The concentrations of 16 PAHs in sediments ranged from 67.9 to $425 \mathrm{ng} / \mathrm{g}$ dry wt; BTs ranged from 2.79 to $14.1 \mathrm{ng} \mathrm{Sn} / \mathrm{g}$ dry wt; NP ranged from 20.7 to $2171 \mathrm{ng} / \mathrm{g}$ dry wt; and coprostanol, a fecal sterol, ranged from 7.60 to $245 \mathrm{ng} / \mathrm{g}$ dry wt. Effective concentration $50 \%\left(\mathrm{EC}_{50}\right)$ of sediments ranged from 0.38 to $23.8 \mathrm{mg} /$ $\mathrm{mL}$. Most of the chemicals were present at levels lower than or comparable to the previously reported values from Korea. However, NP levels in the present study were in the high range of levels reported from the Korean coast, and $40 \%$ of the measured samples exceeded screening and ecotoxicological values of NP suggested by the Netherlands and Canada. This suggests that an ongoing source of NP is a serious concern in the Gunsan coast. High levels of contaminants were found in the proximity of potential sources, such as the outfall of a wastewater treatment plant for NP, an anthracite-fired power plant for PAHs, and ports for BTs, fecal sterols, and sediment toxicity. This indicates that Gunsan coast has various potential sources of marine sediment contaminants.
\end{abstract}

Key words: PAHs, Tributyltin, Nonylphenol, Coprostanol, Bacterial bioluminescence, Sediment pollution

\section{Introduction}

Gunsan, located in the western coast of Korea, is characterized by muddy flat with wide tidal ranges. Fresh water flows into this coast mainly from the Kum River at the eastern end of the coast. The inner part of the coast contains industrial complexes, free trade zones, and international ports. In particular, Gunsan-Gunjang industrial complex was initiated in 1989. It includes motor, ship, and construction machinery industries, and has played a central role in the economies of the Jeonbuk and Gunsan areas, with production and export amounts for 2009 worth USD 2.3 billion, and accounting for $59 \%$ of the total production and $63.2 \%$ of the total exports of Gunsan City (Korea Industrial Complex Corporation, 2011). However, the rapid industrialization of this area has resulted in substantial environmental deterioration that may lead to a variety of social and health problems. Only a few studies have been reported on environmental pollution levels in the Gunsan coast (Kwon et al., 2000; Kim and Jeong, 2003; Seo and Park, 2007), and those studies focused on eutrophication and levels of trace metals. To our knowledge, the present study is the first to investigate concentrations of anthropogenic organic chemicals and to perform sediment toxicity testing in the marine environment of Gunsan.

In this study, the target compounds included tracers of sewage contamination and toxic chemicals; fecal sterols, nonylphenol (NP), polycyclic aromatic hydrocarbons (PAHs), and butyltins (BTs). Coprostanol (COP), a fecal sterol, has been widely used as a tracer of fecal and sewage contamination in aquatic environments because of its high concentrations in hu-
Open Access http://dx.doi.org/10.5657/FAS.2012.0241

This is an Open Access article distributed under the terms of the Creative Commons Attribution Non-Commercial License (http://creativecommons. org/licenses/by-nc/3.0/) which permits unrestricted non-commercial use, distribution, and reproduction in any medium, provided the original work is properly cited. pISSN: 2234-1749 eISSN: 2234-1757
Received 29 December 2011; $\quad$ Revised 1 June 2012; Accepted 9 July 2012

\section{*Corresponding Author}

E-mail: mkchoi3@korea.kr 


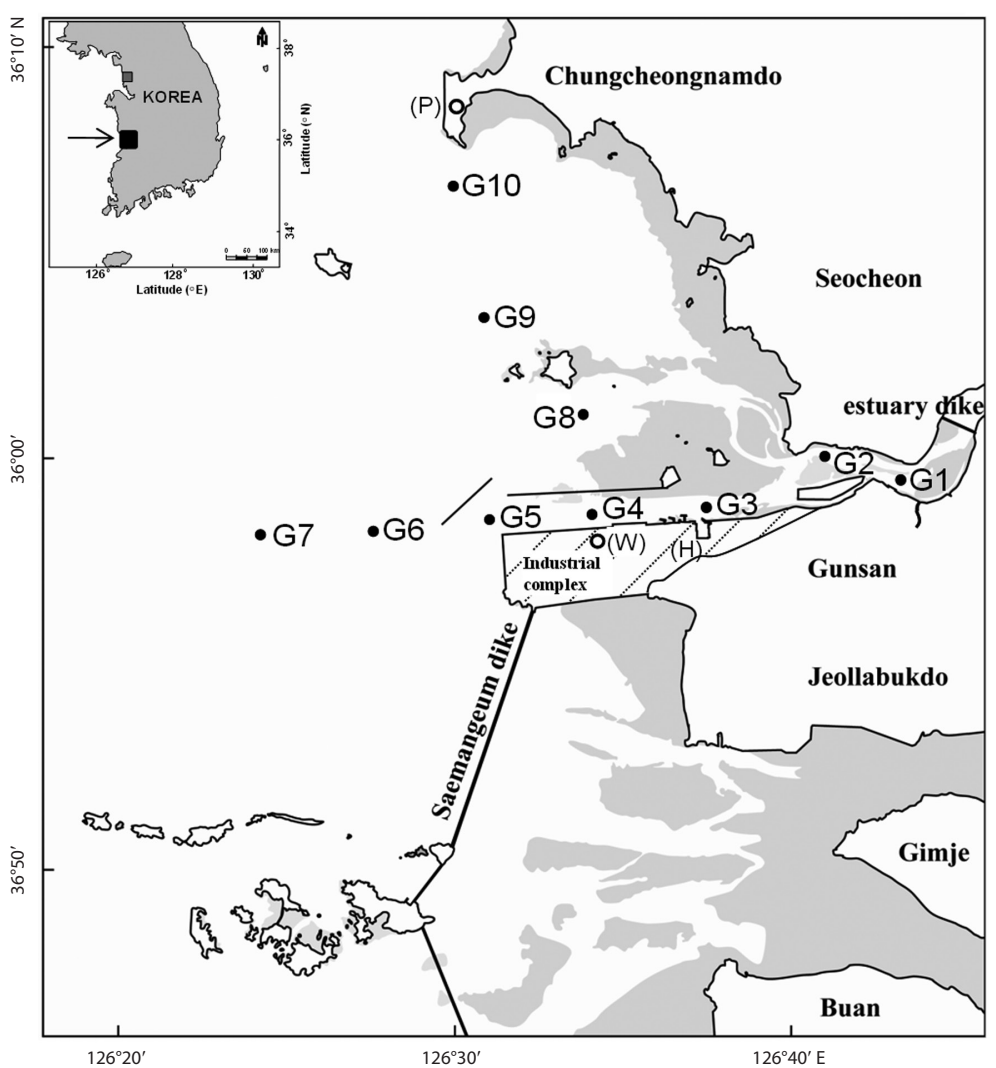

Fig. 1. Sampling locations of marine sediments from Gunsan, Korea. $H$, harbor area; $P$, thermoelctric power plant; W, wastewater treatment plant.

man feces (Chan et al., 1998). NP is a biodegradation product of nonionic surfactants widely used in a various industrial processes, and residential and commercial cleaning products. NP also acts as an endocrine disrupter and is frequently found in effluents from industrial complexes (Bennie et al., 1997; Li et al., 2004; Choi et al., 2011a). COP and NP have been regularly used to investigate the degree of contamination of sediments from wastewater (Noblet et al., 2004; Díez et al., 2006; LaraMartín et al., 2008; Choi et al., 2011a, 2011b).

PAHs are ubiquitous environmental pollutants that primarily result from anthropogenic activities including incomplete fuel combustion, domestic and industrial wastewaters, and the spillage of crude oil and its refined products (Hites et al., 1997; Pettersen et al., 1997). Because PAHs are toxic, carcinogenic, and mutagenic to all organisms including humans, they have been extensively studied in various environmental and biological compartments (Yim et al., 2005; Moon et al., 2007, 2010). BTs are one of the most hazardous pollutants known to occur in aquatic ecosystems. BTs such as tributyltin (TBT) have been widely used as an antifouling paint component on fishing boats, large ships and vessels, harbor structures, and marine platforms. In Korea, TBT in antifouling paints was banned in 2000 because of its adverse biological effects. However, BTs are still detected in aquatic ecosystems and high BT concen- trations have been found in estuaries and harbors (Leung et al., 2006; Berto et al., 2007; Choi et al., 2011b).

The objective of this study was to determine the status of sediment contamination from anthropogenic activities by fecal sterols, NP, PAHs, and BTs. We performed the bioluminescence toxicity test using the bacteria Vibrio fischeri, for the quality assessment of sediments.

\section{Materials and Methods}

\section{Sample collection}

Surface sediments were sampled at 10 locations (G1-G10) in the Gunsan coast in December, 2008 (Fig. 1). Sediment samples were collected systematically from the inner to the outer parts of the coast following the procedure of the National Marine Environmental Monitoring Program in Korea. Sediments samples (0-4 cm depth) were collected by a van Veen Grab sampler, to provide a representative coverage of the coast. The collected samples were individually wrapped in aluminum foil and immediately frozen in a refrigerator on the vessel. Marine sediment samples were transported to the laboratory and were stored at $-20^{\circ} \mathrm{C}$ and freeze dried later. 


\section{Sample preparation}

The detailed descriptions of sediment sample extraction and cleanup procedures for fecal sterols, NP, PAHs, and BTs have been reported previously (Moon et al., 2007; Choi et al., 2010b, 2011a). For NP and fecal sterols, the sediment samples of $5 \mathrm{~g}$ were placed in a $50 \mathrm{~mL}$ Teflon centrifuge tube with a Teflon cap and then digested by mechanical shaking, followed by the spiking of surrogate internal standards for $\mathrm{NP}\left({ }^{13} \mathrm{C}_{6}-\mathrm{NP}\right.$, CLM-4306; Cambridge Isotope Laboratories, Andover, MA, USA) and fecal sterols (1-nonadecanol; Dr. Theodor Schuchardt \& Co., Hohenbrum, Germany). The solutions used to extract the NP and fecal sterols were $20 \mathrm{~mL}$ of $50 \%$ methylene chloride (ultra residue analysis; J. T. Baker, Phillipsburg, NJ, USA) in chloroform (ultra residue analysis; J. T. Baker). In order to purify the NP, the extracts were first derivatized using 99\% bis(trimethylsilyl) trifluoroacetamide with 1\% trimethylchlorosilane (BSTFA; Sigma-Aldrich, St. Louis, MO, USA) and then cleaned by passing through a florisil column with $7 \mathrm{~mL}$ of hexane (ultra residue analysis; J. T. Baker). The extracts to be used for the analysis of fecal sterols were cleaned by passing through a florisil column, with successive elutions with $60 \mathrm{~mL}$ of $40 \%$ hexane in chloroform and $40 \mathrm{~mL}$ of $20 \%$ methanol (ultra residue analysis; J. T. Baker) in chloroform. The second fraction was concentrated and derivatized using BSTFA, then used for the analysis of the fecal sterols.

Briefly, sediment samples of $5 \mathrm{~g}$ were extracted in a Soxhlet apparatus using $200 \mathrm{~mL}$ of $25 \%$ hexane in methylene chloride for $24 \mathrm{~h}$ after spiking with 7 species of internal standards $\left(\mathrm{d}_{8}\right.$ naphthalene, $\mathrm{d}_{8}$-acenaphthylene, $\mathrm{d}_{12}$-fluoranthene, $\mathrm{d}_{10}$-phenanthrene, $d_{10}$-pyrene, $d_{12}$-benzo[a]pyrene and $d_{12}$-benzo[g,h,i] perylene; ES-2044; Cambridge Isotope Laboratories). Both extracts were cleaned by passage through activated silica gel (neutral, 7734, 70-230 mesh; Merck, Darmstadt, Germany) column with successive eluants of hexane and 15\% methylene chloride in hexane. The eluants were concentrated to approximately $50 \mu \mathrm{L}$ and were dissolved with $50 \mu \mathrm{L}$ n-nonane (pesticide analysis grade; Fluka, St. Gallen, Switzerland) for instrumental analysis.

For BTs analysis, $3 \mathrm{~g}$ samples were extracted twice by mechanical shaking with $0.1 \%$ tropolone (Merck, Hohenbrunn, Germany)-methylene chloride, and 50\% $\mathrm{HCl}$ (Merck, Darmstadt)-methanol in $50 \mathrm{~mL}$ Teflon tubes. Tripentyltin chloride (Kanto, Tokyo, Japan) was spiked, as a surrogate standard, before extraction. The extract was hexylated with a Grignard reagent, N-hexylmagnesium bromide (Tokyo Chemical Industry, Tokyo, Japan). The remaining Grignard reagent was removed with $1 \mathrm{~N} \mathrm{H}_{2} \mathrm{SO}_{4}$ (Merck, Hohenbrunn). The organic fraction was decanted, concentrated with a Turbo vap LV (Caliper Life Science Inc., Hopkinton, MA, USA), and then cleaned by passage through a florisil (60-100 mesh, reagent grade; Sigma-Aldrich, Milwaukee, WI, USA) column chromatograph. Finally, tetrabutyltin (Sigma-Aldrich) was added to the concentrated eluants as a recovery standard.

\section{Instrumental analysis}

The detailed conditions of instrumental analysis for fecal sterols, NP, PAHs, and BTs are presented elsewhere (Moon et al., 2007; Choi et al., 2010b, 2011a). In this study, we selected the following 16 non-alkylated PAHs that are listed as priority pollutants by the United Stated Environmental Protection Agency (US EPA): naphthalene (NaP), acenaphthylene (AcPy), acenaphthene (AcP), fluorene (Flu), phenanthrene $(\mathrm{PhA})$, anthracene (AnT), fluoranthene (FluA), pyrene (Pyr), benzo[a]anthracene $(\mathrm{BaA})$, chrysene $(\mathrm{Chr})$, benzo[b]fluoranthene $(\mathrm{BbF})$, benzo[k]fluoranthene $(\mathrm{BkF})$, benzo[a]pyrene $(\mathrm{BaP})$, indeno[1,2,3-c,d] pyrene (InP), dibenzo[a,h]anthracene (DbA), and benzo[g,h,i]perylene (BghiP). The BTs including TBT, dibutyltin (DBT), and monobutyltin (MBT), and the fecal sterols including COP, cholesterol (CHOE), and cholestanol (CHOA), were analyzed. Identification and quantification for target compounds were carried out using a gas chromatograph (Agilent 6890; Agilent Technologies, Inc., Wilmington, DE, USA) coupled with a mass spectrometer (Agilent 5973N). The capillary column used was a DB-5MS (30 m length, 0.25 $\mathrm{mm}$ inner diameter, $0.25 \mu \mathrm{m}$; J\&W Scientific, Folsom, CA, USA). The mass spectrometer was operated under the selected ion monitoring mode using molecular ions of PAHs, BTs, NP, and fecal sterols.

All of the surrogate standards were detected with no interferences. The recovery of surrogates for sediment samples was $90 \pm 6 \%$ for fecal sterols, $84 \pm 8 \%$ for NP, $85 \pm 23 \%$ for PAHs, and $84 \pm 2 \%$ for BTs respectively. Solvents injected before and after the injection of standards showed negligible contamination or carryover. Procedural blanks of sediments were processed in the same way as the samples. Blanks did not contain quantifiable amounts of the target compounds. The calculated detection limit ( $\mathrm{S} / \mathrm{N}=3)$ was $1 \mathrm{ng} / \mathrm{g}$ dry wt for individual PAHs and NP, $0.2 \mathrm{ng} \mathrm{Sn/g} \mathrm{dry} \mathrm{wt} \mathrm{for} \mathrm{BTs,} \mathrm{and} \mathrm{4-5} \mathrm{ng/g}$ dry wt for fecal sterols, respectively.

The total organic carbon (TOC) content in the sediments was determined using a CHN Elemental Analyzer (Model 2400; PerkinElmer, Boston, MA, USA) after the removal of calcium carbonate with $1 \mathrm{~N} \mathrm{HCl}$ (Choi et al., 2007).

\section{Bacterial bioluminescence test by Vibrio fischeri}

Bioluminescence testing was conducted on organic solvent extracts of sediments, based on the standard method of Korea's Ministry of Land, Transport and Maritime Affairs (MLTM, 2010) with some modifications. Detailed descriptions of sediment sample preparation procedures for the bioluminescence testing have been reported previously (Choi et al., 2010b, 2010c). Briefly, 1-2 g of sediment was placed in a $50 \mathrm{~mL}$ Teflon centrifuge tube with a Teflon cap. The sample was extracted twice by mechanical shaking for $1 \mathrm{~h}$ with 20 $\mathrm{mL}$ of $50 \%$ dichloromethane in chloroform, and was centrifuged and then filtrated to minimize the effects of suspended 
particles. Solvent exchanges to the less-toxic dimethyl sulfoxide (ACS reagent; Sigma-Aldrich) were performed. Testing was conducted with an N-TOX system (Model 200; Neoenbiz Inc., Bucheon, Korea) using the organic solvent solubilization method. The determination of toxicity was performed following 30-min contact in all tests.

Potassium dichromate and 3,5-dichlorophenol solutions were purchased from Neoenbiz Inc. for use as reference chemicals. They were run for every fresh vial of bacteria to ensure the validity of all tests. Lyophilised $V$. fischeri bacteria and all bioluminescence reagents were obtained from Neoenbiz Inc. A log-linear model was used to calculate the $50 \%$ effective concentration $\left(\mathrm{EC}_{50}\right)$ with a $95 \%$ confidence limit. The $\mathrm{EC}_{50}$ results are expressed as $\mathrm{mg}$ dry sediment $/ \mathrm{mL}$ aqueous extract.

\section{Statistical analysis}

Spearman correlation analyses were performed to investigate the relationships among chemical concentrations and the toxicity using SPSS version 10.0 (SPSS Inc., Chicago, IL, USA). Non-parametric multidimensional scaling (MDS) was performed to characterize the spatial variability of chemical distributions and sediment toxicity at each of the sampling locations (Fletcher et al., 2001; Moon et al., 2008; Kim et al., 2010b). Bray-Curtis similarities were calculated from squareroot transformed data using PRIMER software for Windows (PRIMER version 5.2.9; Plymouth Marine Laboratories, Plymouth, UK).

\section{Results and Discussion}

\section{Total organic carbon (TOC)}

Concentrations of TOC, fecal sterols, NP, $\mathrm{PAH}$ (the sum of 16 PAH compounds) and $\Sigma$ BT (the sum of MBT, DBT, and TBT) in surface sediment samples are summarized in Table 1. The TOC in Gunsan marine sediments ranged from 0.05

Table 1. Summary of organic chemical concentrations ( $\mathrm{ng} / \mathrm{g}$ dry $\mathrm{wt})$ and toxicity $(\mathrm{mg} / \mathrm{mL})$ in sediments from Gunsan, Korea

\begin{tabular}{|c|c|c|c|c|}
\hline Compounds & Min & Max & Median & Mean \pm SD \\
\hline Total organic carbon $(\%)$ & 0.05 & 0.64 & 0.17 & $0.24 \pm 0.20$ \\
\hline Coprostanol (COP) & 7.60 & 245 & 15.6 & $57.9 \pm 89.2$ \\
\hline Cholesterol (CHOE) & 187 & 447 & 250 & $273 \pm 82.7$ \\
\hline Cholestanol (CHOA) & 61.8 & 188 & 82.4 & $99.3 \pm 46.0$ \\
\hline Nonylphenol (NP) & 20.7 & 2,171 & 190 & $613 \pm 759$ \\
\hline Naphthalene (NaP) & 14.5 & 56.5 & 24.0 & $25.6 \pm 13.0$ \\
\hline Acenaphthylene (AcPy) & 4.47 & 22.9 & 6.32 & $7.89 \pm 5.37$ \\
\hline Acenaphthene (AcP) & 1.37 & 21.7 & 8.06 & $8.10 \pm 6.31$ \\
\hline Fluorene (Flu) & 4.56 & 25.1 & 12.4 & $15.3 \pm 7.85$ \\
\hline Phenanthrene (PhA) & 2.88 & 9.20 & 4.93 & $5.26 \pm 1.79$ \\
\hline Anthrancene (AnT) & $<\mathrm{LOD}^{*}$ & $<\mathrm{LOD}$ & $<\mathrm{LOD}$ & $<\mathrm{LOD}$ \\
\hline Fluoranthene (FluA) & 7.01 & 139 & 42.8 & $51.1 \pm 42.8$ \\
\hline Pyrene (Pyr) & 8.40 & 86.8 & 31.3 & $35.2 \pm 26.4$ \\
\hline Benzo[a]anthracene (BaA) & $<$ LOD & 37.9 & 8.17 & $11.0 \pm 12.2$ \\
\hline Chrysene (Chr) & $<$ LOD & 6.23 & 3.15 & $3.36 \pm 1.82$ \\
\hline Benzo[b]fluoranthene $(\mathrm{BbF})$ & 1.08 & 18.28 & 4.72 & $7.69 \pm 6.19$ \\
\hline Benzo[k]fluoranthene (BkF) & 1.10 & 11.8 & 5.17 & $6.31 \pm 3.59$ \\
\hline Benzo[a]pyrene (BaP) & 1.12 & 57.3 & 15.0 & $16.5 \pm 16.6$ \\
\hline Indeno $[1,2,3-c, d]$ pyrene $(\operatorname{InP})$ & $<$ LOD & 9.74 & 2.64 & $3.79 \pm 3.63$ \\
\hline Dibenzo[a,h]anthracene (DbA) & $<$ LOD & 3.42 & 0.59 & $1.05 \pm 1.13$ \\
\hline Benzo[g,h,i]perylene (BghiP) & $<\mathrm{LOD}$ & 10.8 & 2.30 & $3.80 \pm 4.08$ \\
\hline$\Sigma \mathrm{PAH}$ & 67.9 & 425 & 186 & $202 \pm 119$ \\
\hline$\Sigma \mathrm{CPAH}^{\dagger}$ & 9.96 & 95.5 & 28.0 & $39.2 \pm 26.6$ \\
\hline Monobutyltin (MBT) & 1.03 & 5.47 & 2.34 & $2.60 \pm 1.45$ \\
\hline Dibutyltin (DBT) & 0.93 & 9.38 & 2.30 & $3.46 \pm 2.71$ \\
\hline Tributyltin (TBT) & 0.30 & 0.88 & 0.42 & $0.47 \pm 0.18$ \\
\hline$\Sigma \mathrm{BT}$ (ng Sn/g dry wt) & 2.79 & 14.1 & 4.88 & $6.52 \pm 4.02$ \\
\hline $\mathrm{EC}_{50}^{*}(\mathrm{mg} / \mathrm{mL})$ & 0.38 & 23.8 & 4.53 & $6.02 \pm 7.08$ \\
\hline
\end{tabular}

"Less than limit of detection, ${ }^{\dagger}$ The sum of six potential carcinogenic polycyclic hydrocarbons, ${ }^{\dagger} 50 \%$ effective concentration. 

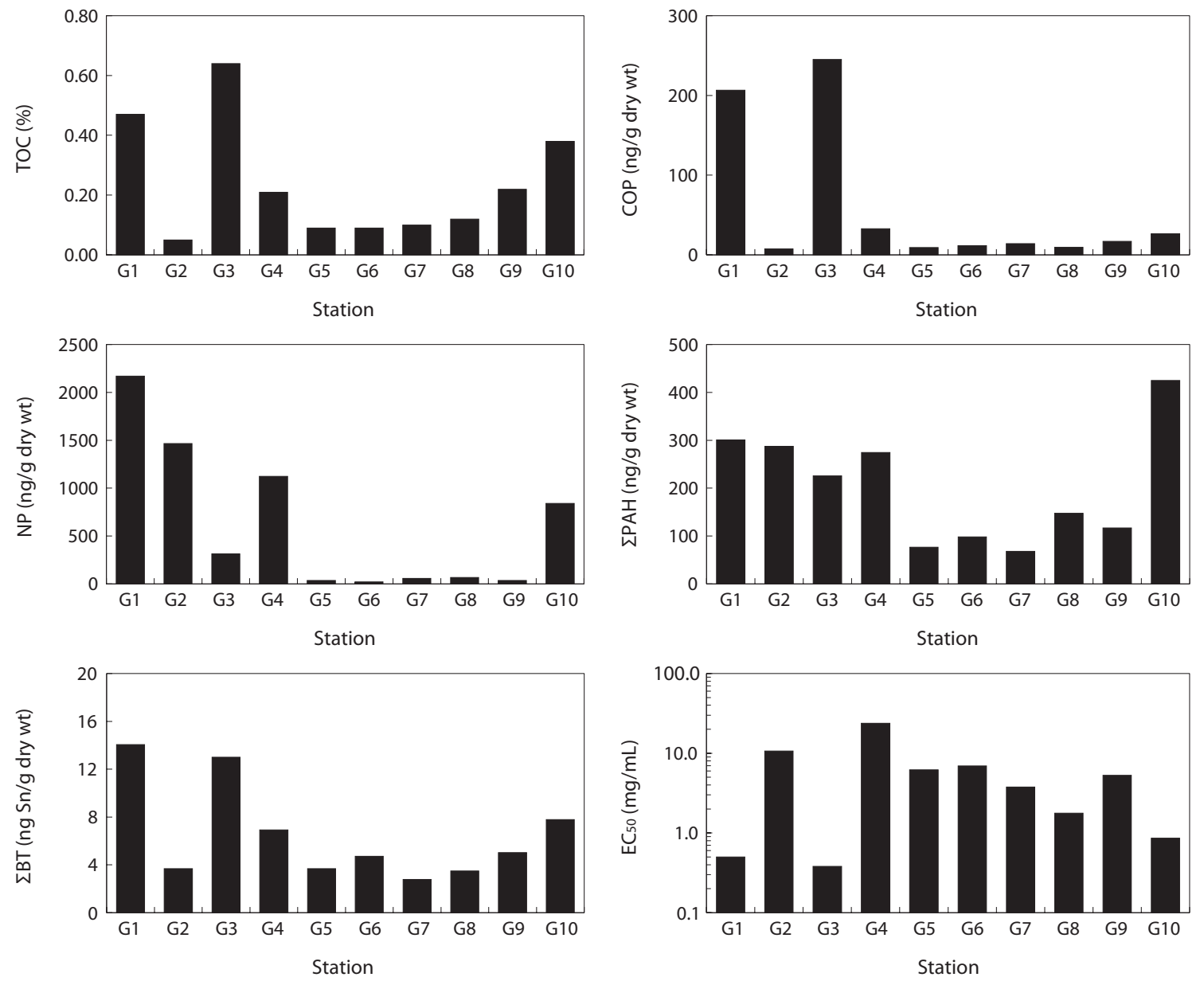

Fig. 2. Spatial distribution of total organic carbon (TOC), coprostanol (COP), nonylphenol (NP), polycyclic aromatic hydrocarbons ( $\mathrm{PAH})$, and butyltins

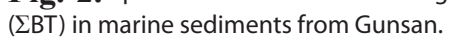

to $0.64 \%$ with a mean value of $0.24 \%$. There are no locations with a TOC content $>3.5 \%$, a level which can pose a high risk for impaired benthic assemblages (e.g., reduced species richness) because of organic loading and other co-varying stressors in sediments (Hyland et al., 2005). TOC contents in the present study were much lower than in other areas of Korea; Masan Bay (3.06-3.76\%) (Choi et al., 2010a), Lake Shihwa (1.40-1.71\%) (Choi et al., 2010a), Ulsan Bay (1.39-1.77\%) (Choi et al., 2010a), and the Mokpo coast (0.42-2.42\%) (Choi et al., 2007).

Site G3 had the highest TOC content in our study, and high contents were also found at sites G1 and G10 (Fig. 2). However, the other sites contained a lower TOC content than the mean content. The correlation of TOC contents in marine sediments was significantly high with COP, and BTs $(r=0.784-$ $0.918, P<0.05)$; however, it was low with NP and PAHs $(r=$ $0.338-0.462, P>0.05)$. This implies that COP and BTs are associated with organic-rich particles, whereas NP and PAHs are associated with local contaminant sources. Moon et al. (2007) and Choi et al. (2007) reported similar patterns for PAHs and
COP in the Mokpo coast.

\section{Fecal sterols and NP}

The concentrations of COP, CHOE, and CHOA were in the ranges of 7.60-245 ng/g dry wt (mean, $57.9 \mathrm{ng} / \mathrm{g}$ dry wt), 187 $447 \mathrm{ng} / \mathrm{g}$ dry wt (273 ng/g dry wt), and 61.8-188 ng/g dry wt ( $99.3 \mathrm{ng} / \mathrm{g}$ dry wt) in surface sediments, respectively. CHOE was the dominant compound in target fecal sterols, accounting for $67 \pm 13 \%$ (mean \pm SD). This may be because CHOE can originate from various sources including wastewater and marine organisms, from plankton to marine mammals. High CHOE concentrations were also reported in Ulsan Bay, Masan Bay, and the Mokpo coast (Choi et al., 2005a, 2005b, 2007). Seven out of the 10 samples had higher concentrations of COP than the background level of $10 \mathrm{ng} / \mathrm{g}$ dry wt (Hatcher and McGillivary, 1979), indicating an impact from fecal pollution in the Gunsan coast. The range of COP values (7.60$245 \mathrm{ng} / \mathrm{g}$ dry wt) in the present study was lower than those previously reported for Kyeonggi Bay (3-3,800 ng/g dry wt) 
(Li et al., 2007), Masan Bay (130-3,964 ng/g dry wt) (Choi et al., 2005b), Ulsan Bay (141-8,257 ng/g dry wt) (Choi et al., 2005a), and the Mokpo coast, Korea (43-7,902 ng/g dry wt) (Choi et al., 2007). In addition, the concentrations of COP in the present study were much lower than those reported in Boston Harbor, USA (260-12,000 ng/g dw) (Eganhouse and Sherblom, 2001), Cootes Paradise, Ontario, Canada (150$38,000 \mathrm{ng} / \mathrm{g} \mathrm{dw}$ ) (Mayer et al., 2007), Santa Monica Bay, USA (70-45,260 ng/g dry wt) (Venkatesan et al., 2010), and Guanabara Bay, Brazil (330-40,000 ng/g dry wt) (Carreira et al., 2004). Therefore, it can be concluded that sewage pollution in the Gunsan coast is low, compared to some other locations worldwide.

The highest concentration of COP, $245 \mathrm{ng} / \mathrm{g}$ dry wt, was found at site G3, which was located near a large port including a cruise terminal. The next highest concentration, $206 \mathrm{ng} / \mathrm{g}$ dry wt, was found at site G1 which was located near a fishing port and the mouth of Gyengpo creek, which passes through the center of Gunsan City (Fig. 2). The concentrations of COP at sites G1 and G3 were approximately four times higher than the mean concentrations. Grimalt et al. (1990) suggested that a range of $0.7-1.0$ for the $\mathrm{COP} /(\mathrm{COP}+\mathrm{CHOA})$ ratio is characteristic of sediment polluted by urban sewage and $<0.3$ is typical of unpolluted sediments. High $\mathrm{COP} /(\mathrm{COP}+\mathrm{CHOA})$ ratios of approximately 0.6 were also reported in locations adjacent to a sewage outfall (Jeong and Han, 1994) and a sewage sludge disposal site (Chan et al., 1998). The ratio in the present study ranged from 0.10 to 0.57 , and its distribution was similar to the COP distribution $(r=0.972, P<0.05)$. The high $\mathrm{COP}$ concentrations and $\mathrm{COP} /(\mathrm{COP}+\mathrm{CHOA})$ ratios at sites G1 and G3 suggest that these locations are impacted by urban sewage.

The concentrations of NP ranged between 20.7 and 2,171 ng/g dry wt (mean, $613 \mathrm{ng} / \mathrm{g}$ dry wt) in surface sediments. In the present study, the NP concentrations in surface sediments revealed contamination levels higher than or comparable to those previously reported for Korean coasts: Mokpo coast (4580 ng/g dry wt) (Choi et al., 2007), Masan Bay (92-600 ng/g dry wt) (Li et al., 2008), Kyeonggi Bay (5-1,100 ng/g dry wt) (Li et al., 2007), Lake Shihwa (10-5,100 ng/g dry wt) (Li et al., 2004; Choi et al., 2011a), and Ulsan Bay (13-5,772 ng/g dry wt) (Choi et al., 2011b). When considering the screening values and ecotoxicological potential of NP, 4 of the 10 samples from the present study exceeded the maximum permissible concentration in The Netherlands (105 ng/g dry wt) (Jonkers et al., 2005). The NP concentrations in these four samples also exceeded the Canadian sediment-quality guideline for NP (1.0 $\mu \mathrm{g}$ NP toxic equivalency/g dry wt [1\% TOC]) (Environment Canada, 2002). This indicates that the Gunsan coast is heavily contaminated by industrial wastewaters including NP.

The high NP concentration recorded in this study may indicate the presence of hot spots directly receiving wastewater treatment plant (WWTP) effluents and/or untreated river waters. The highest concentration of NP, 2,171 ng/g dry wt, was found at site G1, where Gyengpo creek is discharged (Fig. 2). NP concentrations higher than $1,000 \mathrm{ng} / \mathrm{g}$ dry wt were found at sites G2 and G4, located in the proximity of Janghang City and several industrial complexes. In particular, the outfall of WWTP that handles the industrial wastewater was located close to site G4. This suggests that riverine discharges and WWTP effluents are strong potential sources of industrial wastewater in the Gunsan coast. Similar results were reported for Lake Shihwa and Ulsan Bay (Choi et al., 2011a, 2011b). Interestingly, a NP concentration exceeding the screening values, $841 \mathrm{ng} / \mathrm{g}$ dry wt, was detected at site G10 close to the power plant. In Korea, NP is used primarily as a surfactant $(60 \%)$, followed by uses as additives for paints and epoxy resins $(12 \%)$, copper laminates $(9 \%)$, ink binder $(5 \%)$, agricultural pesticides ( $2 \%)$, and other minor uses. The South Korean government designated it as a priority chemical, prohibiting its use as a component of household cleaners in 2002 and all domestic applications in 2007 (Ministry of Environment, 2007). There are no reports regarding the use of NP in power plants, although NP emissions are associated with industrial activities. More intensive monitoring will be needed to identify the sources of NP around this area. The spatial distribution of NP in sediments from the Gunsan coast differed from that for COP $(P=0.138)$, indicating that the potential sources of industrial wastewaters in Gunsan coast differ from those of domestic wastewaters.

\section{Polycyclic aromatic hydrocarbons}

$\Sigma \mathrm{PAH}$ in sediments ranged from 67.9 to $425 \mathrm{ng} / \mathrm{g}$ dry wt (mean, $202 \mathrm{ng} / \mathrm{g}$ dry wt). The sum of the six potential carcinogenic PAHs (the sum of $\mathrm{BaA}, \mathrm{BbF}, \mathrm{BkF}, \mathrm{BaF}, \mathrm{InP}$, and $\mathrm{DbA}$ ) (International Agency for Research on Cancer, 1984), ranged from 9.96 to $95.5 \mathrm{ng} / \mathrm{g}$ dry wt (mean, $39.2 \mathrm{ng} / \mathrm{g}$ dry wt), accounting for $19 \%$ of $\Sigma \mathrm{PAH}$ in sediments. The predominant compounds identified were Pyr, FluA, NaP, BaF, and Flu, collectively accounting for $68 \%$ of $\Sigma \mathrm{PAH}$.

The spatial distribution of $\Sigma \mathrm{PAH}$ in Gunsan sediments showed a clear decreasing trend from the inner to outer locations (Fig. 2). $\Sigma \mathrm{PAH}$ concentrations exhibited significant positive relationships with carcinogenic PAHs $(r=0.867, P$ $<0.05$ ), suggesting that both types of PAHs may have similar sources, transport, and mixing processes, and deposition rates in the coastal region. Concentrations of $\Sigma \mathrm{PAH}$ in the present study were comparable to or higher than those previously reported in Anmyundo (21-103 ng/g dry wt) (Lee et al., 2010), the Taean coast (3.4-158 ng/g dry wt) (Kim et al., 2010a), and the Mokpo coast (4.8-511 ng/g dry wt) (Moon et al., 2007). However, the $\Sigma$ PAH concentrations in the present study were much lower than those previously reported in the following coastal regions: Yeongil Bay (205-10,686 ng/g dry wt) (Moon et al., 2001a), Ulsan Bay (6.0-2,396 ng/g dry wt) (Moon et al., 2001b), Masan Bay (207-2,670 ng/g dry wt) (Yim et al., 2005), Gamak Bay (130-2,100 ng/g dry wt) 
(Kim et al., 2010b), and Gyeonggi Bay (9.1-1,400 ng/g dry wt) (Kim et al., 1999). In addition, the PAH concentrations in Gunsan marine sediments did not exceed the sediment quality guidelines such as the effect range-low $(4,000 \mathrm{ng} / \mathrm{g}$ dry wt and effect range-medium $(45,000 \mathrm{ng} / \mathrm{g}$ dry wt) levels used by the National Oceanic and Atmospheric Administration (Long and Morgan, 1990). Therefore, sediment contamination by PAHs in the Gunsan coast was considered to be low and safe in comparison to those in other environments of Korea.

The highest concentration of $\Sigma \mathrm{PAH}, 425 \mathrm{ng} / \mathrm{g}$ dry wt, was found at site G10 close to an anthracite-fired power plant. The next highest concentration of $\Sigma \mathrm{PAH}$ was found at the inner locations (sites G1, G2, G3, and G4) near Gunsan and Janghang City, where an international cruise terminal and an industrial complex are located. Concentration profiles of PAHs can provide useful information regarding contamination sources in marine sediments (Mille et al., 1982). The ratio of FluA to Pyr $>1$ implies a pyrolytic origin, and the ratio of FluA to Pyr < 1 implies a petrogenic origin of PAHs (Colombo et al., 1989). The ratio of FluA to Pyr ranged from 0.6 to 3.3. Seven of 10 locations exhibited values of FluA to Pyr $>1$, indicating that fossil fuel combustion was the major source of PAHs in the region. In particular, the highest value was found at site G10 close to the power plant. However, some locations such as sites G1, G6, and G7 showed values of FluA to Pyr $<1$. This result indicates both pyrolytic and petrogenic inputs, although inputs of pyrolytic origin predominate at these sites.

\section{Butyltin compounds}

BT was found in all sediment samples and $\Sigma$ BT concentrations ranged from 2.79 to $14.1 \mathrm{ng} \mathrm{Sn} / \mathrm{g}$ dry wt. Concentrations of TBT, DBT, and MBT were in the ranges of $0.30-0.88 \mathrm{ng}$ $\mathrm{Sn} / \mathrm{g}$ dry wt, 0.93-9.38 ng Sn/g dry wt, and 1.03-5.47 ng Sn/g dry wt, respectively. DBT was the main BT compound identified and its proportions accounted for $50 \pm 12 \%$ (mean \pm SD) of the total, suggesting that TBT has no ongoing source in the Gunsan coast. High concentrations of $\Sigma$ BT were observed at sites G1 and G3. However, TBT concentrations in the Gunsan coast are much lower than previously reported in Busan Harbor (4-1,917 ng Sn/g dry wt) (Choi et al., 2009b), Ulsan Harbor (<limit of detection [LOD] to5,372 ng Sn/g dry wt) (Choi et al., 2009b), and Jinhae Bay (< LOD-569 ng Sn/g dry wt (Choi et al., 2009b) which have large commercial ports and shipyards, and along the Korean coast ( $<$ LOD to $782 \mathrm{ng} \mathrm{Sn/g}$ dry wt) (Choi et al., 2009a). In addition, the TBT concentrations in Gunsan marine sediments did not exceed the follow- ing screening and ecotoxicological values: the Australian low and high trigger values (5 and $70 \mathrm{ng} \mathrm{Sn} / \mathrm{g}$ dry wt) (Burton et al., 2005), chronic effects on amphipods and polychaetes (42 ng Sn/g dry wt) (Matthiessen and Thain, 1989), and chronic effects on clam (307 ng Sn/g dry wt) (Langston and Burt, 1991). Therefore, the TBT level in Gunsan marine sediments is considered to be low and safe for aquatic organisms.

\section{Sediment toxicity using Vibrio fischeri}

The $\mathrm{EC}_{50}$ values of sediments ranged from 0.38 to $23.8 \mathrm{mg} /$ $\mathrm{mL}$. The $\mathrm{EC}_{50}$ values of sediments in this study were much higher than those reported in the following Korean coastal regions associated with intensive marine and industrial activities: Masan Bay (0.014-0.089 mg/mL), Lake Shihwa (0.018$0.061 \mathrm{mg} / \mathrm{mL})$, Ulsan Bay $(0.066-1.126 \mathrm{mg} / \mathrm{mL}$ ) (Choi et al., 2010a), and the outfall area of the Masan WWTP (0.014-0.148 $\mathrm{mg} / \mathrm{mL}$ ) (Choi et al., 2010c). However, Southern Puget Sound, USA (0.31-175.30 mg/mL) (Long et al., 2002), the Po River, Italy (0.46-36.80 mg/mL) (Viganò et al., 2003), Waukegan Harbor, USA (0.42-14.50 mg/mL) (Kemble et al., 2000), and the Ebro River, Spain (0.04-12.96 mg/mL) (Ocampo-Duque et al., 2008) were higher or comparable to our results. Therefore, sediment toxicity in the present study is considered within the middle range of toxicities reported worldwide.

Long et al. (2002) suggested critical values of less than $80 \%$ and $90 \%$ of the negative control response, $\mathrm{EC}_{50}<0.51$ $\mathrm{mg} / \mathrm{mL}$ and $<0.06 \mathrm{mg} / \mathrm{mL}$, respectively, to identify toxic samples. Critical values were calculated on the basis of the frequency distribution of Microtox data from US nationwide surveys by the National Oceanic and Atmospheric Administration (NOAA) to denote the $80 \%$ and $90 \%$ lower prediction limits (LPL) of the NOAA Microtox database $(n=1,013)$. In our study, two sites (G1 and G3) produced $\mathrm{EC}_{50}$ values less than $0.51 \mathrm{mg} / \mathrm{mL}(80 \% \mathrm{LPL})$. A relatively low $\mathrm{EC}_{50}, 0.86 \mathrm{mg} /$ $\mathrm{mL}$, was observed at site G10 (Fig. 2).

Spearman rank correlation coefficients between sediment toxicity and chemical levels were estimated (Table 2). The sediment toxicity $\left(\mathrm{EC}_{50}\right)$ was negatively correlated with all contaminant components, suggesting that environmental disturbance by chemical contaminants results in changes in sediment toxicity. The significant negative relationships of sediment toxicity with TOC $(r=-0.754, P<0.05)$ indicate that the sediment toxicity may be associated with organic contamination.

Non-parametric MDS ordination using the sediment toxicity and chemical data for the sampling locations was performed

Table 2. Spearman rank correlation coefficients of sediment toxicity $\left(E C_{50}\right)$ with chemical concentrations

\begin{tabular}{cccccc}
\hline & TOC & Coprostanol & Nonylphenol & $\Sigma$ PAH & \multicolumn{2}{c}{ (BT } \\
\hline$r$-value & -0.754 & -0.552 & -0.170 & -0.236 & -0.419 \\
$P$-value & 0.012 & 0.098 & 0.638 & 0.511 & 0.228 \\
\hline
\end{tabular}

TOC, total organic carbon; $\mathrm{PAH}$, polycyclic aromatic hydrocarbon; BT, butyltin. 


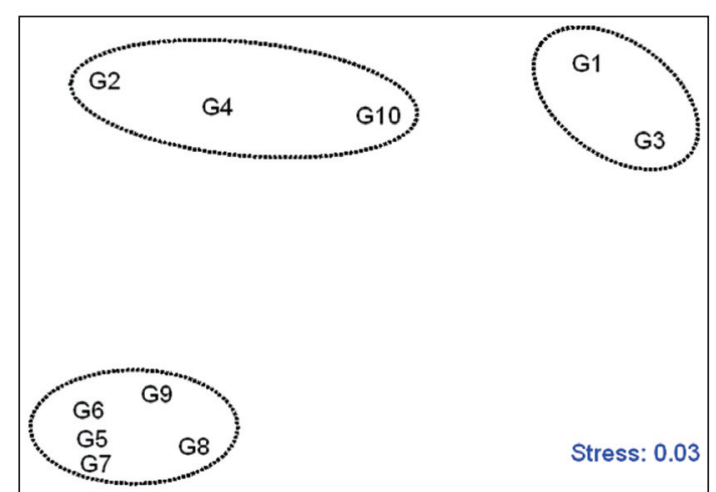

Fig. 3. Non-parametric multidimensional scaling (MDS) ordination plots of chemical data and sediment toxicity data in marine sediments from Gunsan, Korea.

to characterize spatial variations (Fig. 3). Non-parametric MDS suggested three cluster groups among the sampling sites. The stress of the plots was 0.03 ; less than 0.1 represents a good ordination with little chance of misinterpretation (Clark and Warwick, 1994). The first group comprised the sites G1 and G3, which were characterized by severe pollution from organic contaminants (TOC, COP, and BTs), and sediment toxicity. The second group represented sites G2, G4, and G10, which were characterized by relatively high concentrations of contaminants related to industrial activity (NP and PAHs) compared to those in the first group. The other group was the remaining sites G5, G6, G7, G8, and G9, which were characterized by relatively low contaminant concentrations owing to the long distances from inland sources and the influence of stronger currents. Therefore, anthropogenic organic pollution in the Gunsan marine sediments is considered to be mainly affected by point sources including the WWTP and the power plant, and ports with high shipping traffic for both cruises and fishing boats.

\section{Acknowledgments}

We thank our colleague, Ji-Eun Park for assistance for chemical analyses. This work was funded by a grant from the National Fisheries Research and Development Institute (NFRDI, RP-2012-ME-45), Korea.

\section{References}

Bennie DT, Sullivan CA, Lee HB, Peart TE and Maguire RJ. 1997. Occurrence of alkylphenols and alkylphenol mono- and diethoxylates in natural waters of the Laurentian Great Lakes basin and the upper St. Lawrence River. Sci Total Environ 193, 263-275.

Berto D, Giani M, Boscolo R, Covelli S, Giovanardi O, Massironi M and Grassia L. 2007. Organotins (TBT and DBT) in water, sedi- ments, and gastropods of the southern Venice lagoon (Italy). Mar Poll Bull 55, 425-435.

Burton ED, Phillips IR and Hawker DW. 2005. In situ partitioning of butyltin compounds in estuarine sediments. Chemosphere 59, 585592.

Carreira RS, Wagener ALR and Readman JW. 2004. Sterols as markers of sewage contamination in a tropical urban estuary (Guanabara Bay, Brazil): space-time variations. Estuar Coast Shelf Sci 60, 587598.

Chan KH, Lam MHW, Poon KF, Yeung HY and Chiu TKT. 1998. Application of sedimentary fecal stanols and sterols in tracing sewage pollution in coast. Water Res 32, 225-235.

Choi M, Choi HG, Kim SS and Moon HB. 2005a. Evaluation of sewagederived organic matter using fecal sterols in the sediments from Ulsan Bay and adjacent areas. J Environ Sci 14, 23-32.

Choi M, Moon HB, Kim SS and Lee Y. 2005b. Distribution of sewagederived organic matter using fecal sterol in Masan Bay, Korea. J Environ Sci 14, 481-490.

Choi M, Choi HG, Moon HB, Yu J, Kang SK and Choi SK. 2007. Sources and distributions of organic wastewater compounds on the Mokpo Coast of Korea. J Fish Sci Technol 10, 205-214.

Choi M, Choi HG, Moon HB and Kim GY. 2009a. Spatial and temporal distribution of tributyltin (TBT) in seawater, sediments and bivalves from coastal areas of Korea during 2001-2005. Environ Monitor Assess 151, 301-310.

Choi M, Moon HB, Yu J, Eom JY and Choi HG. 2009b. Butyltin contamination in industrialized bays associated with intensive marine activities in Korea. Arch Environ Contam Toxicol 57, 77-85.

Choi M., Kim SG, Yoon SP, Jung RH, Moon HB, Yu J and Choi HG. 2010a. Sediment toxicity of industrialized coastal areas of Korea using bioluminescent marine bacteria. Fish Aquat Sci 13, 244-253.

Choi M, Moon HB, Yu J, Eom JY and Choi HG. 2010b. Temporal trend of butyltins in seawater, sediments, and mussels from Busan Harbor of Korea between 2002 and 2007: tracking the effectiveness of tributyltin regulation. Arch Environ Contam Toxicol 58, 394-402.

Choi M, Park Y, Moon HB, Yoon SP, Jung RH, Yu J and Choi HG. 2010c. Bioluminescence Inhibition Test (Vibrio fischeri) for Surface Sediments from Wastewater Treatment Plant Effluent Outfall Area. J Korean Soc Environ Anal 13, 92-98.

Choi M, Furlong ET, Moon HB, Yu J and Choi HG. 2011a. Contamination of nonylphenolic compounds in creek water, wastewater treatment effluents, and sediments from Lake Shihwa and vicinity, Korea: Comparison with fecal pollution. Chemosphere 85, 14061413.

Choi M, Moon HB and Choi HG. 2011b. Tracing wastewater contamination in sediments from Ulsan Bay of Korea using nonylphenolic compounds. J Korean Soc Environ Anal 14, 5-11.

Clark KR and Warwick RM. 1994. Change in Marine Communities: An Approach to Statistical Analysis and interpretation. Natural Environment Research Council, Polymouth, GB.

Colombo JC, Pelletier E, Brochu C, Khalil M and Catoggio JA. 1989. Determination of hydrocarbon sources using n-alkane and polyaromatic hydrocarbon distribution indexes: Rio de la plata Esturary, Argentina. Environ Sci Technol 23, 888-894. 
Díez S, Jover E, Albaigés J and Bayona JM. 2006. Occurrence and degradation of butyltins and wastewater marker compounds in sediments from Barcelona harbor, Spain. Environ Int 32, 858-865.

Eganhouse RP and Sherblom PM. 2001. Anthropogenic organic contaminants in the effluent of a combined sewer overflows: impact on Boston Harbor. Mar Environ Res 51, 51-74.

Environment Canada, 2002. Canadian Environmental Quality Guidelines for Nonylphenol and Its Ethoxylates (Water, Sediment, and Soil) for the Protection of Aquatic Life: Nonylphenol and Its Ethoxylates. National Guidelines and Standards Office, Environmental Quality Branch, Environment Canada, Report 1-3, Ottawa, ON, CA.

Fletcher R, Reynoldson TB and Taylor WD. 2001. The use of benthic mesocosms for the assessment of sediment contamination. Environ Pollut 115, 173-182.

Grimalt JO, Fernandez P, Bayona JM and Albaiges J. 1990. Assessment of fecal sterols and ketones as indicators of urban sewage inputs to coast. Environ Sci Technol 24, 357-363.

Hatcher PG and McGillivary PA. 1979. Sewage contamination in the New York Bight, coporstanol as an indicator. Environ Sci Technol 13, 1225-1229.

Hites RA, Laflamme RE and Farrington JW. 1997. Polycyclic aromatic hydrocarbons in recent sediments: the historical record. Science 198, 829-831.

Hyland J, Balthis L, Karakassis I, Magni P, Petrov A, Shine J, Vestergaard O and Warwick R. 2005. Organic carbon content of sediments as an indicator of stress in the marine benthos. Mar Ecol Prog Ser 295, 91-103.

International Agency for Research on Cancer (IARC). 1984. IARC Monographs on the Evaluation of the Carcinogenic Risk of Chemicals to Humans. International Agency for Research on Cancer, Lyon, FR.

Jeong WL and Han BC. 1994. Sedimentary coprostanol in Kaohsiung Harbor and the Tan-Shui Estuary, Taiwan. Mar Poll Bull 28, 494499.

Jonkers N, Laane, RWPM, De Graaf, C and De Voogt, P. 2005. Fate modeling of nonylphenol ethoxylates and their metabolites in the Dutch Scheldt and Rhine estuaries: validation with new field data. Estua Coast Shelf Sci 62, 141-160.

Kemble NE, Hardesty DG, Ingersoll CG, Johnson BT, Dwyer FJ and MacDonald DD. 2000. An evaluation of the toxicity of contaminated sediments from Waukegan Harbor, Illinois, following remediation. Arch Environ Contam Toxicol 39, 452-461.

Kim GB, Maruya KA, Lee RF, Lee JH, Koh CH and Tanabe S. 1999. Distribution and sources of polycyclic aromatic hydrocarbons in sediments from Kyeonggi Bay, Korea. Mar Poll Bull 38, 7-15.

Kim HC, Lee WS, Hwang UK and Choi YS. 2010a. Variation in the residual oils in the culture grounds on the Taean coast, Korea after the Hebei Spirit oil spill. Korean Fish Aquat Sci 43, 705-714.

Kim JG and Jeong TJ. 2003. A study on eutrophication control in coastal area of Gunsan. J Environ Sci 12, 957-966.

Kim YH, Choi M, Jung RH, Yoon SP, Yu J, Choi HG, Ahn SM, and Moon HB. 2010b. Distributions of polycyclic aromatic hydrocarbons and fecal sterols in sediment from Gamak Bay and their im- pact on benthic community. J Korean Soc Environ Anal 13, 1-10. Korea Industrial Complex Corporation. 2011. Industrial Park Development in Korean Economy: A Guideline for Development and Management of Industrial Parks. Korea Industrial Complex Corporation. Seoul, Korea. p.152.

Kwon JN, Kim JG and You SJ. 2000. Characteristics of water quality and factor analysis on the variations of water quality in coastal sea around the Keum River Estuary in Summer. J Korean Soc Mar Environ Eng 3, 3-22.

Langston WJ and Burt GR. 1991. Bioavailability and effects of sediment-bound TBT in deposit-feeding clams, Scrobicularia plana. Mar Environ Res 32, 61-77.

Lara-Martín PA, Gómez-Parra A and González-Mazo E. 2008. Sources, transport and reactivity of anionic and non-ionic surfactants in several aquatic ecosystems in SW Spain: a comparative study. Environ Pollut 156, 36-45.

Lee WS, Park SY, Kim PJ, Jeon SB, An KH and Choi YS. 2010. Pollution of polycyclic aromatic hydrocarbons (PAHs) in seawater and marine sediments from Anmyundo coastal area after oil spill. J Environ Sci 19, 1421-1430.

Leung KMY, Kwong RPY, Ng WC, Horiguchi T, Qiu JW, Yang R, Song M, Jiang G, Zheng GJ and Lam PKS. 2006. Ecological risk assessments of endocrine disrupting organotin compounds using marine neogastropods in Hong Kong. Chemosphere 65, 922-938.

Li D, Kim M, Oh JR and Park J. 2004. Distribution characteristics of nonylphenols in the artificial Lake Shihwa, and surrounding creeks in Korea. Chemosphere 56, 783-790.

Li D, Shim WJ, Dong M and Hong SH. 2007. Application of nonylphenol and coprostanol to identification of industrial and fecal pollution in Korea. Mar Poll Bull 54, 97-116.

Li D, Dong M, Shim WJ, Yim UH, Hong SH and Kannan N. 2008. Distribution characteristics of nonylphenolic chemicals in Masan Bay environments, Korea. Chemosphere 71, 1162-1172.

Long ER and Morgan LG. 1990. The Potential for Biological Effects of Sediment-sorbed Contaminants Tested in the National Status and Trends Program. Technical Memorandum NOS OMA 52. National Oceanic and Atmospheric Agency (NOAA), Rockville, MD, US.

Long ER, Dutch M, Aasen S, Welch K, Hameedi J, Magoon S, Carr RS, Johnson T, Biedenbach J, Scott KJ, Mueller C and Anderson JW. 2002. Sediment Quality in Puget Sound: Year 3 Southern Puget Sound. NOAA Technical Memorandum NOS NCCOS CCMA No. 153. National Oceanic and Atmospheric Administration, Silver Spring, MD, US.

Matthiessen P and Thain JE. 1989. A method for studying the impact of polluted marine sediments on intertidal colonising organisms: tests with diesel-based drilling mud and tributyltin anti-fouling paint. Hydrobiology 188/189, 477-485.

Mayer T, Bennie D, Rosa F, Rekas G, Palabrica V and Schachtschneider J. 2007. Occurrence of alkylphenolic substances in a Great Lakes coastal marsh, Cootes Paradise, ON, Canada. Environ Poll 147, 683-690.

Mille G, Chen JY and Dou HJM. 1982. Polycyclic aromatic hydrocarbons in Mediterranean coastal sediments. Int J Environ Anal Chem 11, 295-304. 
Ministry of Environment (MOE). 2007. A designation of nonylphenolic compounds as the restricted chemical in Korea. [Internet]. Environmental Policy Office, Department of Hazardous Chemical Management, Seoul, Korea, Accessed 10 Mar 2011, http://me.go. $\mathrm{kr} /$ kor/notice/notice_02_01.jsp?id=notice_02\& $\operatorname{mode}=$ view\&i $\mathrm{dx}=160334$.

Ministry of Land, Transport and Maritime Affairs (MLTM). 2010. Standard Methods for Marine Environmental Analysis. Ministry of Land, Transport and Maritime Affairs, Seoul, Korea, p. 495.

Moon HB, Choi HG, Kim SS and Lee PY. 2001a. Distribution of polycyclic aromatic hydrocarbons in seawater and sediment from Yeongil Bay, Korea. J Korean Soc Environ Anal 4, 149-157.

Moon HB, Choi HG, Kim SS and Lee PY. 2001b. Level and origin of polycyclic aromatic hydrocarbons in sediments from Ulsan Bay, Korea. J Korean Soc Environ Sci 10, 113-119.

Moon HB, Kang SK, Kim HS, Choi M, Yu J, Choi HG and Park JS. 2007. Polycyclic aromatic hydrocarbons (PAHs) in seawater and marine sediments from Mokpo Coast in Korea. J Korean Soc Environ Anal 10, 83-90.

Moon HB, Yoon SP, Jung RH and Choi M. 2008. Wastewater treatment plants (WWTPs) as a source of sediment contamination by toxic organic pollutants and fecal sterols in a semi-enclosed bay in Korea. Chemosphere 73, 880-889.

Moon HB, Kim HS, Choi M, and Choi HG. 2010. Intake and potential health risk of polycyclic aromatic hydrocarbons associated with seafood consumption in Korea from 2005 to 2007. Arch Environ Contam Toxicol 58, 214-221.
Noblet JA, Young DL, Zeng EY and Ensari S. 2004. Use of fecal steroids to infer the sources of fecal indicator bacteria in the Lower Santa Ana River Watershed, California: sewage is unlikely a significant source. Environ Sci Technol 38, 6002-6008.

Ocampo-Duque W, Sierra J, Ferré-Huguet N, Schuhmacher M and Domingo JL. 2008. Estimating the environmental impact of micropollutants in the low Ebro River (Spain): an approach based on screening toxicity with Vibrio fischeri. Chemosphere 72, 715-721.

Pettersen H, Näf C and Broman D. 1997. Impact of PAH outlets from an oil refinery on the receiving water area: sediment trap fluxes and multivariate statistical analysis. Mar Pollut Bull 34, 85-95.

Seo MS and Park YS. 2007. Geochemical characteristics of surface sediments in the Keum River Estuary adjacent to coastal area. J Fish Mar Sci Educ 19, 1-7.

Venkatesan MI, Merino O, Baek J, Northrup T, Sheng Y and Shisko J. 2010. Trace organic contaminants and their sources in surface sediments of Santa Monica Bay, California, USA. Mar Environ Res 69, 350-362.

Viganò L, Arillo A, Buffagni A, Camusso M, Ciannarella R, Crosa G, Falugi C, Galassi S, Guzzella L, Lepez A, Mingazzini M, Pagnotta R, Patrolecco L, Tartari G and Valsecchi S. 2003. Quality assessment of bed sediments of the Po River (Italy). Water Res 37, 501-518.

Yim UH, Hong SH, Shim WJ and Chang M. 2005. Spatio-temporal distribution and characteristics of PAHs in sediments from Masan Bay, Korea. Mar Poll Bull 50, 319-326. 